Remedios Mataix Azuar

Doctora en Filología Hispánica

Desempeña su actividad docente como Profesora Titular de literatura hispanoamericana en la Universidad de Alicante. Su labor como investigadora se ha centrado en la literatura hispanoamericana de los siglos XIX y XX, y en sus relaciones con los procesos culturales y socio-políticos. Ha dedicado atención especial a la obra de José Lezama Lima y el Grupo Orígenes, al estudio del Modernismo, y a la tematología y la iconología americanas, temas sobre los que ha dictado cursos y conferencias en varias universidades españolas, europeas e hispanoamericanas, y sobre los que es autora de numerosas publicaciones.

\section{ANDROCENTRISMO, EUROCENTRISMO, RETÓRICA COLONIAL: AMAZONAS EN AMÉRICA}

\author{
REMEDIOS MATAIX \\ Universidad de Alicante \\ remedios.mataix@ua.es
}

\title{
RESUMEN
}

El trabajo examina cómo el arquetipo clásico de la Amazona renace y se reinventa al calor de la encrucijada cultural que fue el 'Descubrimiento', cómo viaja de Europa a América y cómo, finalmente, regresa para incorporarse al imaginario hispánico siendo ya un referente nuevo que sustenta simbólicamente el arraigo de una «lógica» de la conquista, y convertido en un tropo de la dominación de América que exhibe valores simbólicos redundantes con la concepción providencialista de tal empresa, homogeneizadora, vertical, jerárquica y patriarcal, a la que todos los autores de la época (peninsulares y virreinales) se acogieron.

Palabras clave: androcentrismo, eurocentrismo, amazonas, imaginario colonial, iconología americana.

\section{ABSTRACT}

This article examines the rebirth and reinvention of the classic archetype of the Amazon in the cultural melting-pot of the «Discovery», how this image travels from Europe to America, and how on its final voyage becames part of hispanic imagery. This image used by authors of the time both on the mainland and in the vicekingdoms, portrays a «logic» regarding the conquest of America and represents the symbolic values of the endevour which are homogenizing, vertical, hierarchical and patriarchical.

Keywords: Androcentrism, Eurocentrism, Amazons, Colonial Imaginary, Latin American Iconology.

Es sobradamente conocido que la reproducción o el trasplante en territorio americano de los mitos y leyendas procedentes de la Antigüedad y la Edad Media tuvo una profunda incidencia sobre las primeras configuraciones imaginarias del nuevo continente que emprendieron los europeos contemporáneos a su hallazgo. El fenómeno obedece en buena medida a la necesidad de Occidente de identificar, reconocer y encontrar referentes aplicables a un mundo desconocido, inespera- do, lleno de novedades naturales, humanas y morales, que además tuvo el significado trascendental de desestabilizar y poner en tensión casi todos los saberes y creencias aceptados, y que permanecía invisible salvo a través de los relatos y cartografías titubeantes ofrecidos por sus primeros exploradores. A ese tan Nuevo Mundo se asomará la curiosidad de los habitantes del Viejo, desde muy poco después del primer contacto colombino, con la construcción y fijación de una imagen simbólica, 
que aparecerá con enorme recurrencia en las artes del Renacimiento y el Barroco, en la que resulta especialmente significativa la feminización de aquella tierra: para representar al Otro, la alteridad absoluta que era América, la imaginación europea, tan eurocéntrica y androcéntrica, acudió a la tradicional feminización de la naturaleza conquistada (un tropo recurrente del pensamiento colonizador por lo menos desde Hesíodo), como parte de ese fenómeno inevitable -lo fue para europeos y americanos- de inserción de lo desconocido que aparecía repentinamente en los paradigmas explicativos de la propia tradición. En el caso europeo, los espacios y las costumbres del otro americano fueron estructurados a partir de un horizonte de expectativas heredado del mundo clásico, pero no deja de resultar llamativo que en ese proceso, y de entre el amplio repertorio mítico de lugares y seres fantásticos que los conquistadores llevaron consigo y esperaban encontrar, la resonancia de las Amazonas, esas hábiles guerreras protagonistas de memorables episodios históricomitológicos de la Antigüedad, ocupara un lugar fundamental en la formulación y consolidación de una alegoresis americana ${ }^{1}$ en la que el rasgo femenino exacerbó los atributos otorgados al Nuevo Mundo como alteridad exótica, fascinante y peligrosa.

Lo que me interesa examinar es cómo el arquetipo clásico de la Amazona renace y se reinventa al calor de la encrucijada cultural que fue el 'Descubrimiento', cómo viaja de Europa a América (hasta el punto de constituir una presencia recurrente en la toponimia del continente) y cómo, finalmente, a bordo de los primeros textos que daban cuenta del hallazgo, regresa para incorporarse al imaginario hispánico y europeo siendo ya un referente nuevo, o al menos profundamente resemantizado, que sustenta simbólicamente el surgimiento y arraigo de una «lógica»-que simultáneamente activa mythos y logos, simbolismo y racionalidad- de la conquista.

El mito original de ese pueblo exclusivamente femenino, ginecocrático y belicoso lo conforma la amplia tradición textual e iconográfica de amazonomaquias ('combates con las Amazonas'), una de las pruebas obligadas que todo héroe de la mitología griega tenía que enfrentar y superar. Según esas fuentes², las Amazonas, hijas de la ninfa Harmonía y el violento Ares y oriundas de la región del Cáucaso, habrían vivido en Escitia en un pasado lejano, pero luego se trasladaron a las márgenes de un río de múltiples brazos que recibía el nombre de Termodón o Termodonte, en Capadocia. A su mala reputación, reforzada por su 'nacionalidad' asiática (la pugna Europa-Asia es una constante que guía el curso de la Historia Antigua), se le atribuía también el sometimiento de múltiples pueblos para la fundación de varias ciudades (Esmirna, Éfeso, Cime, Mirina, Pafos) donde constituían su Estado gobernado siempre por una reina, así como la penetración en Lesbos, Samotracia, Beocia y Ática. Sus disputas con los griegos se remontan en el tiempo hasta más atrás de las aventuras de Belerofonte, quien las derrotó tras ser encargado de expulsarlas por el rey de Licia, con la esperanza de que encontrase la muerte entre aquéllas que habían vencido hasta a los atlantes y los gorgones. Los argonautas de Jasón, después de haber pasado una temporada feliz entre ellas en la isla de Lemnos, tuvieron que enfrentarlas, y las bravas mujeres atacaron también a los frigios, que fueron ayudados por el entonces joven Príamo, quien, no obstante, hacia el final de la guerra de Troya, contó con la colaboración contra los griegos de sus antiguas oponentes bajo el mando de su reina Pentesilea, que sería muerta y amada (en ese orden) por Aquiles.

Pero fueron las campañas de Heracles/ Hércules las que más popularidad les dieron: por haber sido enviado el héroe en su «noveno trabajo» al País de las Amazonas en busca del cinturón de oro de Ares que llevaba otra de sus reinas, Hipólita, y por haber sido ese episodio -que, aunque Hipólita ofrece el cinturón sin resistencia, acaba con una lucha encarnizada entre griegos y amazonas por causa de un engaño de Hera- el origen probable del asalto de las Amazonas sobre Atenas en combate contra Teseo, quien, participante en la expedición de Heracles, había raptado (o seducido y abandonado) a la princesa amazona Antíope (también llamada Glauce o Melanipe, según las versiones), desatando así la ira amazónica. La batalla terminó, según los atenienses, con una aplastante victoria griega que sirvió de motivo mítico para ilustrar el triunfo contra los persas y que confinó para siempre a las «contranaturales» Amazonas a un lugar y un estatus imaginario situados siempre «más allá», en lo exterior, en lo salvaje, en lo bárbaro, fuera del orden establecido, más allá de los límites de la civilización occidental. Desde allí cortarán el paso imperial de

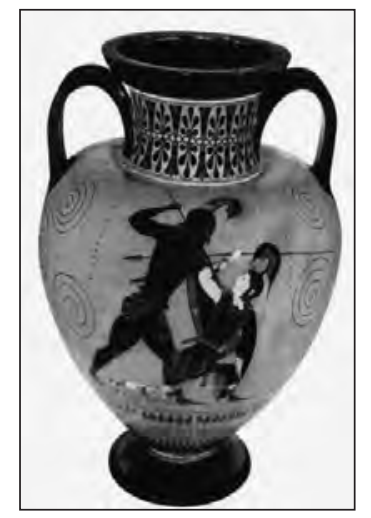

«Aquiles y Pentesilea», cerámica ática de Exekias, ca. 525 aC.

1

Manejo el término habitual en los estudios de emblemática e iconología para delinear las diferencias entre alegoría (la 'técnica', el producto, la figura -literaria, iconográfica, emblemática- definida ya por la retórica clásica como continua metaphora) y alegoresis: el 'método' o proceso imaginario que permite entender la fijación del significado de una alegoría y su persistencia tradicional.

2

Resumo en estos párrafos información procedente de la Biblioteca Mitológica de Apolodoro (1985), donde se intenta conciliar las distintas versiones que ofrecían de cada mito los poetas de la Antigüedad, así como de Carlos Alonso del Real (1967), Donald J. Sobol (1973), William Tyrrel (1990), y Robert Graves (2004).
Androcentrismo, eurocentrismo, retórica colonial: amazonas en América

REMEDIOS MATAIX 


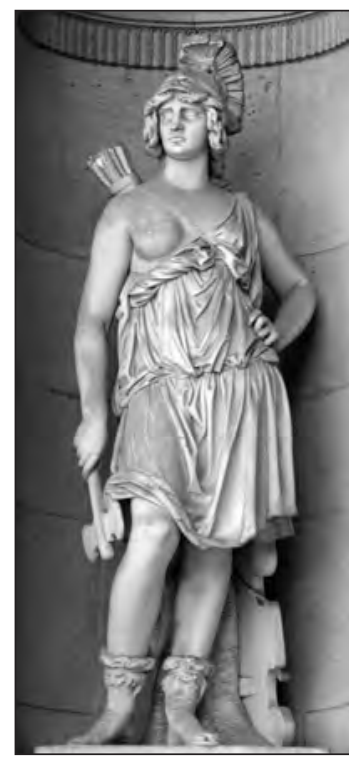

«La amazona Pentesilea» (1862), de Gabriel-Vital Dubray.

3

Aunque es ésa la etimología más popular entre los clásicos -relacionable con la tradición etiológica según la cual las amazonas se mutilaban o quemaban el pecho derecho para poder usar el arco sin ese "obstáculo» femenino-, algunos autores hablan del valor aumentativo de la alfa inicial o bien de la significación de mathon como 'luna' (lo que podría concordar con el culto de las Amazonas a divinidades lunares como Ártemis), y el término podría derivar también del iraní ha-mazan ('todas mujeres') o del persa hamazakaran ('mujeres que hacen la guerra'). Véase García Sanz, 1998.

4

Es una idea consensuada ya entre los estudiosos de la Antigüedad. Para las fuentes concretas de mis reflexiones, véanse Walcot (1984), Tyrrell (1984), Said (1985), Blok (1995) y Diago Marco (2009)

Androcentrismo, eurocentrismo, retórica colonial: amazonas en América

REMEDIOS MATAIX

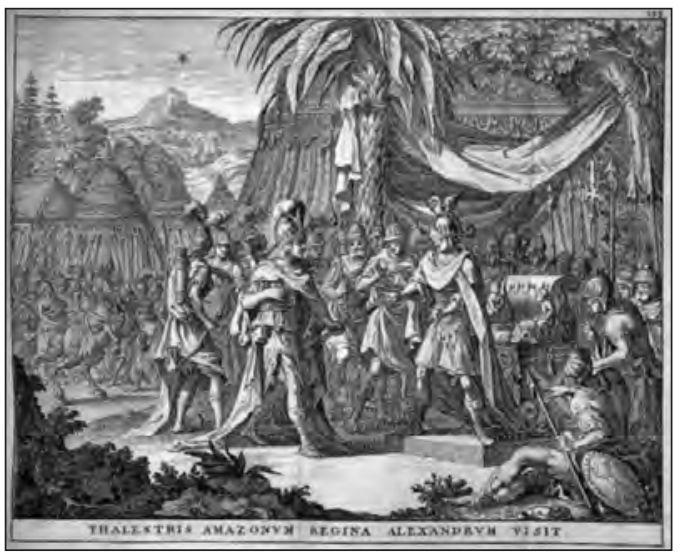

"Talestris, reina de las Amazonas, visita a Alejandro». Grabado anónimo de 1696 sobre el Libro de Alexandre.

Alejandro Magno, según todas sus Historias (pues la reina Talestris o Calectrix, a la cabeza de trescientas amazonas más, permaneció con el rey macedonio por trece días y noches con la esperanza de iniciar una estirpe tan fuerte e inteligente como ambos), y, desde allí, con el transcurrir de las centurias, se las hará internarse cada vez más en el Oriente, bien en las «tierras del Catay», según la Embajada a Tamerlán (2004, p. 258), bien en un misterioso río «sin nacimiento ni fin» en los confines de la India, según el Pseudo Calístenes (1977, III, p. 25), hasta que el cristianismo, tan poco propenso al protagonismo femenino, las sitúe confraternizando con las hordas del Anticristo junto a las ubicuas Puertas Caspias de la literatura sagrada y profética, que, significativamente, recogerá el Libro de las profecías que Cristóbal Colón redactara, posiblemente entre 1500 y 1501, en beneficio de una idea mesiánica y providencial de la empresa descubridora que habría de influir en gran medida en los autores posteriores (Colón, 1984).

Entre los rasgos peculiares de esa sociedad 'otra', además de las notas básicas de belicosidad, ginecocracia y matriarcado, están el aborrecimiento del matrimonio, el ser «enemigas de los hombres»-incluso andróctonas ('asesinas de varones'), según $\mathrm{He}$ rodoto- y no admitirlos entre sí salvo para puntuales ceremonias anuales de procreación que aseguraran la perpetuación de su estirpe, y la selección sexual del producto de esos «matrimonios de visita»: sólo aceptaban a las criaturas de sexo femenino, que pasaban a integrarse a la comunidad amazónica, y los varones eran sacrificados, enviados de vuelta con sus padres o abandonados a su suerte. Sobre su aspecto, fijado a lo largo de la his- toria del arte, sabemos que era fiero y algo varonil, que su vestidura consistía bien en el traje escita con pantalones ajustados y una túnica hasta la cintura ceñida por un cinturón que cruza el pecho, o bien en ir vestidas a la griega, con la clámide abierta por el costado, dejando al descubierto su único pecho (y de ahí una posible etimología: de a-mathon, 'sin pecho's). La cabeza solía cubrirse con el gorro frigio o con un casco llamado alopekis, y sus únicos ornamentos eran sus armas: flechas, arco y aljaba, a veces un hacha, y la montura a caballo.

Pero es el denso valor simbólico de la Amazona el que me interesa subrayar, porque la erige en paradigma de la Otredad idóneo para ser aplicado al contexto de la conquista de América, dado que, bien como personificación del enemigo fantástico, bien (o a la vez) como representación de la inversión teratológica de los papeles sexuales que encarna esa mujer convertida en sujeto autónomo y guerrero, la Amazona constituye una suerte de exterioridad enemiga y amenazante del mundo civilizado y de la experiencia humana nor$\mathrm{mal}^{4}$, cuyo mundo es el reverso de los valores respetados en la polis; una figura antípoda del orden establecido -que para el imaginario androcéntrico europeo ha de ser femenina- en la que confluyen los peligros de la barbarie, la amenaza de una inversión del patriarcado occidental y los terrores inconscientes masculinos proyectados sobre la feminidad (se trata de una población no griega, bárbara, cuya vida cotidiana se basa en el uso de las armas y en la guerra, con instituciones y normas de tipo matriarcal, y un universo religioso femenino), y con la que se constituye un mito inversor que confirma el ordenamiento (masculino) del mundo conocido.

Como tales llegan ya las Amazonas al imaginario fundacional de 1492 habiendo atravesado los siglos XII al XV, que fueron especialmente receptivos para con las resonancias fantásticas de esas mujeres belicosas (me refiero a su difusión en obras claves de la literatura como el Roman d'Eneas, el Roman de Troie y el Roman d'Alexandre, por citar sólo los ejemplos más sobresalientes), cuya existencia dejaba fuera de toda duda el ya imponente número de escritos y de tradiciones orales que describían la nación femenina, y cuya creciente popularidad la confirma su insistente aparición no sólo en los libros de viajes más célebres de la época (Marco Polo, 
John de Mandeville, Pero Tafur), sino además en obras de erudición tan influyentes en el ámbito hispánico como las dos Estorias de Alfonso X o las Etimologías de San Isidoro, $\mathrm{y}$ hasta en los numerosos repertorios medievales y renacentistas que ofrecían modelos y antimodelos de la virtud femenina. Pero será a partir de la difusión de los primeros descubrimientos colombinos cuando la revitalización del mito amazónico en la imaginación europea vaya adquiriendo los nuevos atributos ( $\mathrm{y}$ los nuevos matices semánticos) que servirán para caracterizar imaginariamente a América como lo que hemos llamado una «antípoda femenina» vertida en los moldes de la Amazona clásica y definida de acuerdo con las oposiciones básicas de la retórica colonial que nombra al otro desde la posición epistemológica inamovible de quien nombra: nosotros/ los otros, civilizados/ salvajes, cultura/ naturaleza y masculino/ femenino. Esa dialéctica, unida a la suposición -apriorísticamente irrebatible desde la inevitable perspectiva del conquistador civilizado, cristiano y 'superior' que ostenta Europa- de la entusiasta disposición de los 'salvajes' indígenas a «quedar nuestros» y convertirse en «buenos servidores», como ya estableció Colón (1989, p. 30), admitió enseguida una acepción erótica y fuertemente ambivalente en el imaginario de los discursos sobre una América-Amazona, a la vez disponible y hostil, seductora y siniestra, capaz de excitar a la vez el temor y el deseo. Ella será la alegórica depositaria de los contenidos ideológicos, morales, convencionales, fantásticos o fantasmáticos claves en los procesos intelectuales de asimilación de lo otro, lo nuevo, lo desconocido, además de resumir con exactitud las motivaciones de conquistadores y viajeros, ligadas a los intereses monárquicos o a los deseos particulares de los marinos.

Ya en el primer atlas moderno de la historia, el célebre e influyente Theatrum Orbis Terrarum (1570) de Abraham Ortelius, cuya principal novedad era precisamente la inclusión del Nuevo Mundo en ese teatro de la Tierra hasta entonces de concepción tripartita, quedaría fijada esa imagen de América como Amazona salvaje aunque receptiva al «abrazo amoroso» con el conquistador (Ortelius, 1570, p. 5), que la Iconología (1593) de Cesare Ripa y otros manuales teóricos sancionarían como alegoría canónica: una figura femenina que, aunque mantiene la «fiereza» y las armas emblemáticas de su antecesora



América según la lconología de Cesare Ripa.

clásica («ha de sostener un arco, y una flecha con la diestra, poniéndosele al costado una bolsa o carcaj bien provista de flechas»), se representa canónicamente como una espléndida mujer semidesnuda de senos turgentes (a diferencia de su homónima mitológica, la amazona americana conserva los dos pechos), adornada sólo con penacho o cinturón de plumas, y generalmente acompañada por grandes reptiles u otras citas de la fauna autóctona estereotipadas ya como criaturas malignas y abundantes en América, además de por «una cabeza o extremidades humanas traspasadas por alguna de las saetas», pues «aquellas gentes, dadas a la barbarie, acostumbran generalmente a alimentarse de carne humana, comiéndose a aquellos hombres que han vencido en la guerra, así como a los esclavos que compran y otras víctimas, según las ocasiones» (Ripa, 2007, II, pp. 108-110).

Esa América quedaría con Ripa dispuesta a ofrecer resultados tan espectaculares en la historia del arte como las esculturas de François Guérin (1678) en el Palacio de Versalles, los frescos de Andrea Pozzo en Roma (1694), los de Francesco Mura en La Granja (1738), los de Giambattista Tiepolo en Wutzburg (1753) y Madrid (1767), o la orfebrería de Lorenzo Vaccaro (1741) en la Catedral de Toledo, entre otros muchísimos ejemplos célebres. Con ellos asistimos a una fascinante superposición de datos procedentes de las primeras descripciones etnográficas elaboradas por los cronistas de Indias, de influjos y sugestiones ejercidos por el gusto, las creencias, los prejuicios o la tradición, todo ello vertido en los moldes

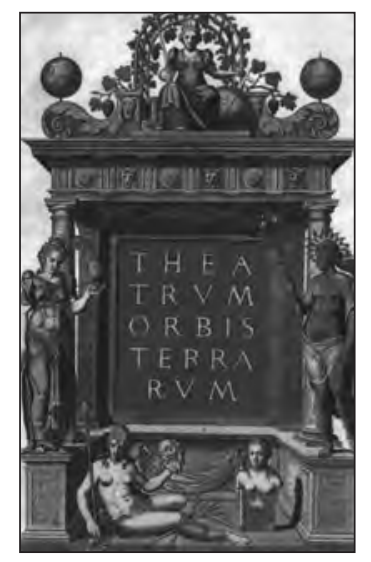

Las Cuatro partes del Mundo (Europa, Asia y África presentan a «la India América», que ocupa el lugar central inferior, antípoda del de Europa). Frontispicio alegórico del Theatrum Orbis Terrarum (1570), de Abraham Ortelius.

Androcentrismo, eurocentrismo, retórica colonial: amazonas en América

REMEDIOS MATAIX 


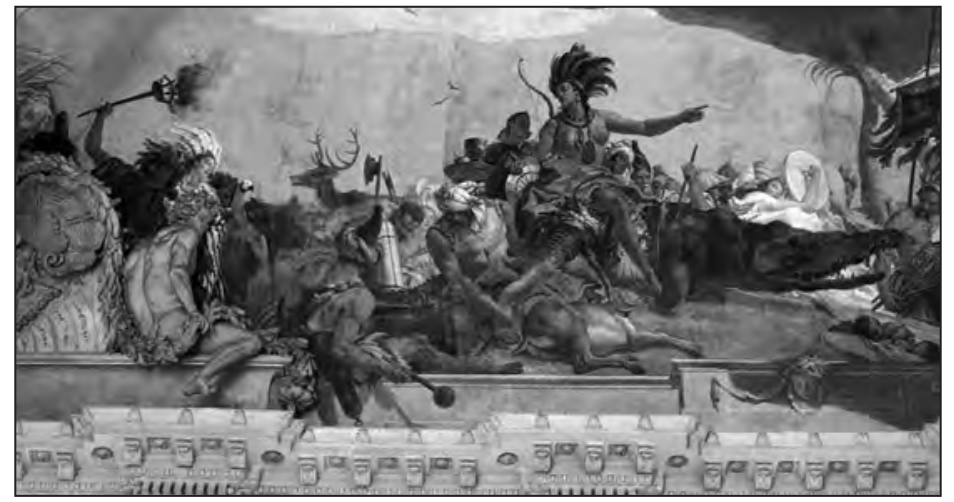

Giambattista Tiepolo, América (Alegoría de Apolo y los cuatro continentes, 1753). Palacio del Príncipe-Obispo de Wutzburg.

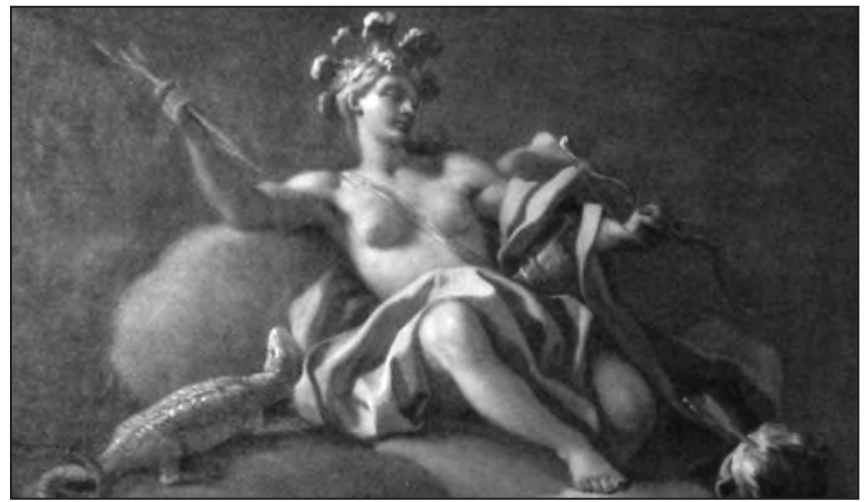

Francesco Mura, América (1738). Segovia, Palacio de La Granja.
5 Para un recorrido más detallado por esos trasvases que sólo puedo apuntar aquí, remito a mis trabajos «Redescubriendo América: el modelo cronístico en la narrativa del Mundonovismo» (2009a) y «Las cinturas de América. Alegoresis, recurrencias y metamorfosis en la iconología americana» (2009b). Sobre la alegoría de América en el teatro hispánico, véanse los excelentes trabajos de Miguel Zugasti, 1998 y 2006.

6

Véase Polo, 1983, 456-458. Colón leerá atentamente esos pasajes, cuyo relato se afianzó imaginariamente también de la mano del Libro de las maravillas del mundo (1356) atribuido a John de Mandeville, del Atlas Catalán (1375) atribuido a Abraham Cresques, cuya plancha séptima representa las Islas de las Mujeres en el extremo Oriente, o del célebre Imago Mundi de Pierre D’Ailly (1410), y se mantenía vigente casi dos siglos más tarde en el globo terráqueo de Martín Behaim (1492), que aún recogía las islas Masculina y Femenina.

7

Aunque entre los clásicos no faltan ejemplos de Amazonas devoradoras de carne humana (Esquilo, Las suplicantes), basta recordar que el pueblo más salvaje ya en el repertorio de Herodoto eran los androphagoi o 'comedores de hombres' (Historia, I). Como manifestación extrema de la ausencia de civilización (son "salvajes agresivos sin sentido del bien ni del mal»), los define lo que no tienen ni conocen, como la recurrente

\footnotetext{
Androcentrismo, eurocentrismo, retórica colonial: amazonas en América

REMEDIOS MATAIX
}

representativos vigentes de una cultura de las imágenes notablemente proclive en la época a la comunicación simbólica, lo que determinará una 'idea' de América y de las diferencias entre el 'nosotros' europeo y el 'ella' americano que, entre otras cosas, marcará el paso de la leyenda geográfica a toda una alegoría del nuevo continente, cuyo extraordinario aprovechamiento teatral (en solitario o en el prototipo iconográfico de las Cuatro Partes del Mundo) seguirá al pie de la letra los ornamentos marcados por la Iconología renacentista y es fácilmente rastreable también en la literatura peninsular, la colonial y la hispanoamericana, hasta bien entrado el siglo $X^{5}$.

Los cimientos de esa construcción tan resistente fueron, lógicamente, responsabilidad de Colón. El Almirante, sin duda teniendo en mente las islas Femenina y Masculina de Marco Polo y de la cartografía medieval y renacentista ${ }^{6}$ (y tal vez también el recurrente dato de la desnudez de los «lindos cuerpos de mugeres» que recorre sus textos) no tarda en encontrar la pista y consigna ya en el diario de su primer viaje la noticia de que «hazia Leste avía una isla adonde no avía sino solas mujeres» (1989, p. 109). Una semana más tarde, se apresta a salir de la Española en misión de exploración y así confirma la proximidad de Cipango, del oro y de una isla llamada Matinino «que era toda poblada de mugeres sin hombres, y armadas, y que en ella ay muy mucho 'tuob' qu'es oro o alambre». Colón se entusiasma con la idea de «llevar a los Reyes cinco o seis»

desnudez -lo es de vestidos, de cultura, de valores, de moral- que caracterizará invaria- de esas mujeres y recopila cuanta información le ofrecen los naturales. Sabemos así que «era cierto que las avía», que «cierto tiempo del año venían los hombres a ellas de la isla de Carib (...), y si parían niño enbiávanlo a la isla de los hombres, y si niña, dexávanla consigo» (Ibid., pp. 115-119), y que Colón decidió zarpar hacia esa isla, aunque el calamitoso estado de sus embarcaciones impuso el regreso a España, desde donde las noticias de su expedición reactualizarán por primera vez la creencia en las Amazonas. En la carta a Luis de Santángel (1493), el primer documento oficial que informa de sus descubrimientos (y que se difundirá inmediatamente en multitud de ediciones y traducciones europeas: once sólo ese mismo año), el Almirante describe Matinino como «la primera isla partiendo de España para las Indias que se falla, en la cuál no ay hombre ninguno». Se dice de sus mujeres que «no usan exercicio femenil, salvo arcos y flechas», que «se arman y cobigan con launes de arambre, de que tienen mucho", y que son los feroces caribes/ caníbales, "los cuales comen carne umana», quienes ayudan a perpetuar la sociedad de esas nuevas amazonas de Matinino (Ibid., pp. 144-145), de acuerdo con otro de los topoi de la alteridad clásica operante sobre la conquista de América?.

Colón no consiguió llegar a esa isla de las mujeres (aunque su flota sí recibió una lluvia de flechas lanzada por ellas), pero no descartó nunca su existencia: la situó siempre un poco más allá, en una tierra aún incógnita o aún «no subjetada»-como aquellas ubicuas Puertas Caspias- donde, además, se suponía que estaban los metales deseados, pues en aquella Matinino, como en la Isla Hembra de Marco Polo, había también «mucho oro». Ya en su segundo 
viaje encomienda a Fray Ramón Pané para que fuera a vivir entre los taínos, aprendiera su lengua, indagara sobre sus creencias y sus ritos, y relatara por escrito todo aquello que pudiese averiguar. Producto de ese importante encargo, para el que Pané vivió dos años entre los naturales de la Isabela, fue la Relación acerca de las antigüedades de los Indios (publicado en 1571, pero el primer libro escrito en un idioma europeo en el Nuevo Mundo), donde se certifica la existencia de esa isla Matinino, en la que, según la versión de Fray Ramón, «no hay más que hembras» desde que el fundador mítico Guaguyona las dejara allí y se fuera a otra región llamada Guanín, donde "quedaron todos los hombres sin mujeres» (Pané, 1974, p. 36). Pero, independientemente de fenómenos de verdadero amazonismo americano como ése (cuya presencia extendida en la región ilustran innumerables mitos de origen y ha sido confirmada por la antropología contemporánea), a fines del siglo XV esas «repúblicas femeninas», cuyas componentes se dedican a ejercicios varoniles, especialmente la guerra, demuestran capacidad de navegación, se unen a los hombres (antropófagos caribes de un estadio cultural inferior) con fines exclusivamente procreadores y practican el nomadismo, no podían ser asociadas más que a las Amazonas de la Antigüedad. Colón las imaginará recorriendo las inmensidades de Asia hasta su asentamiento actual (prolongación del originario, según lo que cree haber descubierto el Almirante) en Matinino, la isla más extrema de las Indias o la primera que encontraría cualquier navegante al atravesar el Océano. Y desde 1493, con la primera de sus Décadas, Pedro Mártir de Anglería difunde la insólita novedad ultramarina de las mujeres solas en términos acordes con esa relectura:

En el primer viaje de Colón habían tenido los nuestros noticias de esta isla Madanina [sic]. Se ha creído que los caníbales se acercan a aquellas mujeres en ciertos tiempos del año, del mismo modo que los robustos tracios pasan a ver a las Amazonas de Lesbos, según refieren los antiguos, y que de igual manera ellas les envían los hijos destetados a sus padres, reteniendo consigo a las hembras. Cuentan que estas mujeres tienen grandes minas debajo de tierra, a las cuales huyen si alguno se acerca a ellas fuera del tiempo convenido; pero si se atreven a seguirlas por la violencia o con asechanzas y acercarse a ellas, se defienden con saetas, creyéndose que las disparan con ojo muy certero (1989, p. 17).

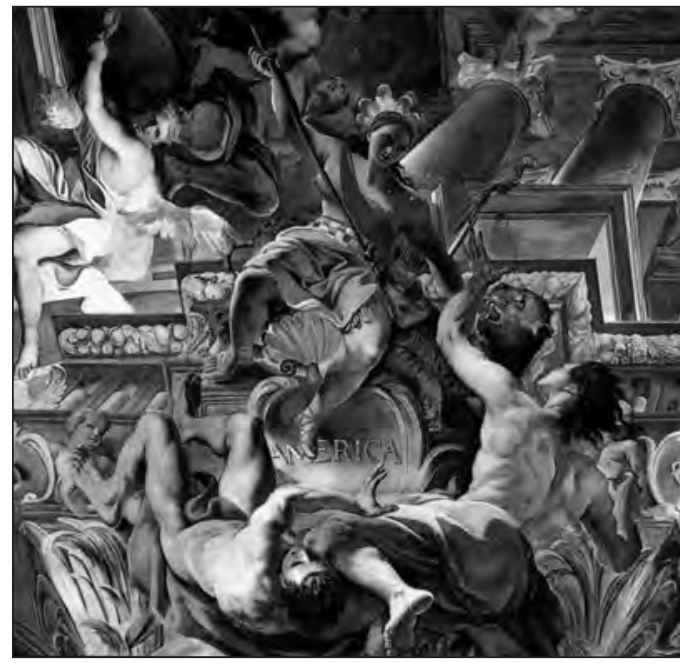

Andrea Pozzo, América (1694). Roma, Iglesia de San Ignacio.

Ya Gonzalo Fernández de Oviedo, en la Historia General y Natural de las Indias (1535), la primera obra que intentaba entregar una visión conjunta de todo lo americano, de enorme influencia sobre los designios de la Corona española y sobre las ideas de sus contemporáneos, entiende y explica claramente esa-diríamos hoy- superposición del imaginario clásico sobre la insólita realidad del Nuevo Mundo: Oviedo recoge cuantos datos y relaciones al respecto existían hasta entonces, por sus páginas desfilan las reinas Conori, Orocomay y cuantas «mugeres que en las Indias viven por sí sin varones, é son señoras sobre sí, a imitaçión de las Amaçonas, e militan en la guerra, e son poderosas e ricas e poseen grandes provincias» (2007, p. 222), $\mathrm{y}$ en su libro VI dedica todo un capítulo a introducirnos y prevenirnos sobre el tema, estableciendo cuáles son las 'verdaderas' amazonas («aquellas que los antiguos llamaron amaçonas, porque para ejercitar el arco y las flechas, seyendo niñas, les cortaban o quemaban la teta derecha, e no les crescía, e dejaban la siniestra para que pudiesen criar la hija que pariesen; $y$ en griego a quiere decir sin, e mazos quiere decir teta, y por esto, amazona quiere decir sin teta») y cuáles las que «los cristianos comenzaron a llamar amaçonas, sin lo ser, impropiamente» (porque "aquestas mujeres flecheras de quien aquí tratamos, no se cortan la teta ni se la queman", aunque "en otras cosas, como ayuntarse hombres de cierto tiempo para su aumentación, paresce que imitan a aquellas que los antiguos llamaron amaçonas», Ibid., p. 123), cuya existencia y

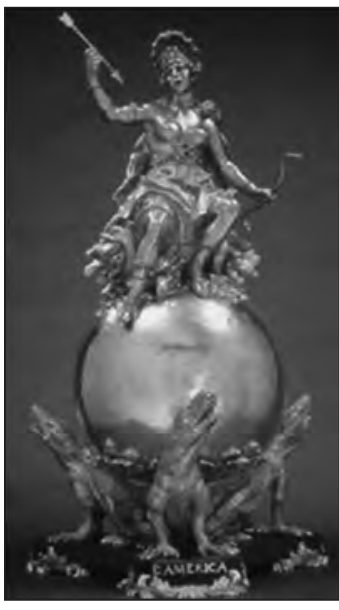

Lorenzo Vaccaro, América (1741). Tesoro de la Catedral de Toledo.
Androcentrismo, eurocentrismo, retórica colonial: amazonas en América

REMEDIOS MATAIX 


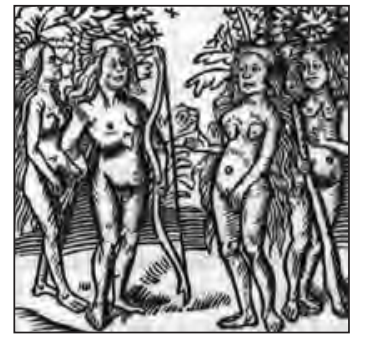

Grabado de una hoja volante (1505) sobre la epístola Mundus Novus de Americo Vespucci.

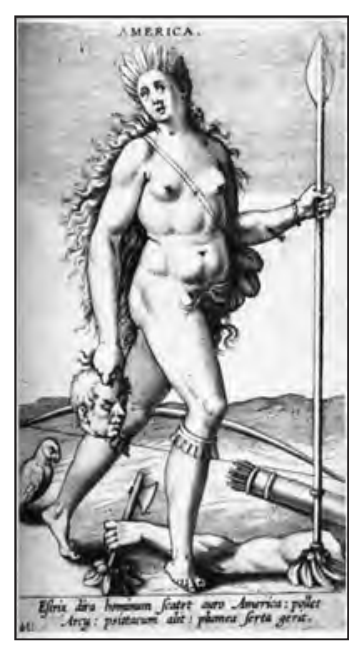

Philippe Galle, América (Proso pographia, 1579).
Androcentrismo, eurocentrismo, retórica colonial: amazonas en América

REMEDIOS MATAIX

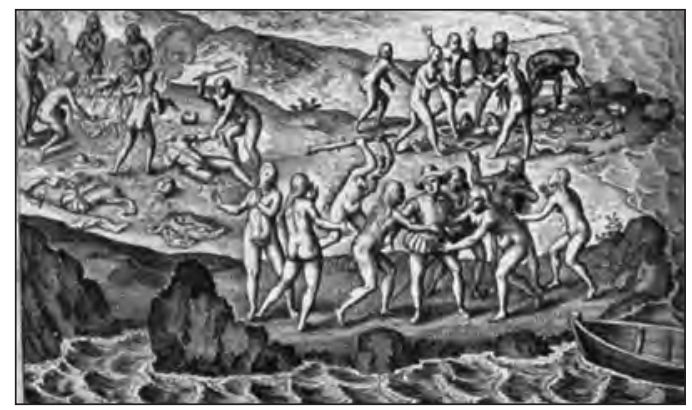

Ilustración para la Lettera de Amerigo Vespucci... (Frankfurt, 1628).

denominación sanciona el autor en la célebre Carta al cardenal Bembo sobre la Navegación del Amazonas (1543) en términos ya nada titubeantes, «...pues en lo demás no les es poco anexo el estilo de su vida, pues estas viven sin hombres y señorean muchas provincias y gentes, $\mathrm{y}$ en cierto tiempo del año llevan hombres a sus tierras, con quienes han sus ayuntamientos y después que están preñadas los echan de la tierra, y si paren hijo o le matan o le envían a su padre, y si es hija la crían para aumento de su república; y en esto hay mucho que decir $\mathrm{y}$ todas esas mujeres obedecen y tienen una reina muy rica y ella y sus principales señoras se sirven en vajillas de oro, según por oídas y relaciones de indios se sabe» (apud. Asensio, 1949, p. 34).

Es decir: excepto para Colón, que, creyéndose en Asia, buscó a las legendarias Amazonas bien en calidad de "pieza clave de identificación» o de «prueba definitiva de haber arribado en efecto a la India fabulosa» (Pastor, 1983, p. 16), a juzgar por los textos, ningún otro cronista o explorador lo hará. Lo que se buscaba eran unas nuevas amazonas (ésas que servirían de molde a la feminidad simbólica autóctona de la que hemos hablado), pues, como ha matizado José Carlos González Boixo, «la tradicional perspectiva que ve las empresas de conquista como fruto de una credulidad extraordinaria en todo tipo de leyendas» debería ceder paso a la idea comprobable de que «detrás de cada uno de esos mitos [de la conquista] aparentemente incitadores para realizar expediciones, hay una realidad que da un sesgo mucho más racional a la empresa» (1996, p. 54). Sin embargo, aquella asociación colombina entre las mujeres solas, la antropofagia y el oro sí experimentará una enorme fortuna imaginaria y definirá la función de las mujeres guerreras en el proceso de descubrimiento y conquista como elemento anunciador de la proximidad de riquezas infinitas y como metáfora para todo territorio americano difícil de conquistar. Un ejemplo muy elocuente de ello son ya las cartas de Americo Vespucci en que describe sus viajes a Suramérica (me refiero a la Epistola Mundus Novus de 1502, el primer texto en que América es nombrada con ese sintagma, y a la Lettera di Amerigo Vespucci delle isole nuovamente trovate in quattro suoi viaggi, de 1505), también rápidamente impresas y distribuidas por toda Europa acompañadas de expresivos grabados que arraigan en el imaginario occidental esa variante de la amazona americana desde la perspectiva androcéntrica-colonial de que hemos hablado.

De esas mujeres belicosas, que van armadas pero desnudas y "sin vergüenza de sus vergüenzas», se añade que son «lujuriosas sin medida» y que se mostraban «muy deseosas de ayuntarse con nosotros los cristianos» (Vespucci, 1951, p. 217), aunque, como corresponde a su salvajismo, los seduzcan sexualmente para después comérselos: el texto de Vespucci y su traducción en imágenes cuentan que los cristianos mandaron a uno de sus hombres, «un joven muy esforzado», a mediar con un grupo de mujeres «indias de cueva» que se mostraban hostiles: «Cuando llegó junto a ellas le hicieron un gran círculo alrededor, y tocándolo y mirándolo se maravillaban. Y estando en esto vimos venir una mujer del monte que traía un gran palo en la mano; y cuando llegó donde estaba nuestro cristiano, se le acercó por detrás y, alzando el garrote, le dio tan gran golpe que lo tendió muerto en tierra. En un instante las otras mujeres lo cogieron por los pies, y lo arrastraron así hacia el monte». Más tarde se comprobó que allí «estaban las mujeres despedazando al cristiano y en un gran fuego que habían hecho lo estaban asando a nuestra vista, mostrándonos muchos pedazos y comiéndoselos» (ibid., pp. 265-266).

Tales escenas impresionaron la imaginación europea por muchos años y fueron repetidas o recreadas por muchos otros cronistas, viajeros e historiadores, así como invariablemente trasladadas a la imagen en la mayoría de las ediciones ilustradas de los textos de Vespucci, lo que da indicios del interés que despertaban sus significados profundos.

En ellos, entre otras consecuencias fantasmáticas, el canibalismo va unido a la promiscuidad y la lascivia porque todos significan 
exceso de apetitos; una destemplanza 'monstruosa' con la que la amazona América exhibirá su condición de salvaje (un ser sin restricciones culturales y por tanto perverso) y se hará depositaria de la representación emblemática tradicional de pecados como la Lujuria y la Gula -antropófaga en este caso-mediante imágenes femeninas, o de arquetipos universales referidos a la Mujer Fatal, seductora y voraz (brujas, diablesas, sirenas, gorgonas), para convertirse en lugar de confluencia entre el mito de los antropófagos proveniente de la Antigüedad, el discurso de la barbarie cristiana y los terrores inconscientes masculinos proyectados sobre la feminidad. Entre ellos el fantasma omnicultural y diacrónico de la vagina dentata, vinculado desde antiguo a algunos mitos amazónicos -tanto europeos como de la América prehispánica- en que los hombres vivieron subyugados a las mujeres hasta que les arrancaron los dientes de sus vaginas y las convirtieron en penetrables (Carranza Aguilar, 2000, p. 7) , renacido en el mundo medieval cristiano de la mano del célebre Malleus Maleficarum (1486) y la misoginia inquisitorial, y subyacente tanto al relato de Vespucci sobre el joven esforzado (las mujeres lo seducen para devorarlo) como, en otra de sus variantes fantasmáticas -la castración-, a otras muchas aventuras sexuales relatadas en la cronística americana9.

De la supuesta hostilidad hacia el hombre de esas mujeres antropófagas que viven solas en sus islas o sus cuevas se desprenden las configuraciones imaginarias que acabarían por vincular semántica e imaginariamente al Otro que nombra a América con el canibalismo imputado a los aborígenes en conjunto, como ilustra la truculenta visión de los miembros humanos mutilados que para la segunda mitad del siglo XVI acompañan ya convencionalmente a las alegorías de América como 'canibalesa' de apetitos extremos y devoradora del hombre europeo que camina entre restos humanos, y que se popularizó en Europa hasta el grado emblemático. Algunas de las más difundidas fueron la de Philippe Galle (1581), quien dedica a América el número 43 de sus Personificaciones y la describe como una mujer que «es rica en oro», pero también salvaje y fiera que «devora a los hombres», que va desnuda salvo por un tocado de plumas y que se arma con arco, flechas y lanza emplumada, y la de Crispijn Van Passe (1596), que recibe cabezas y miembros humanos como ofrenda.

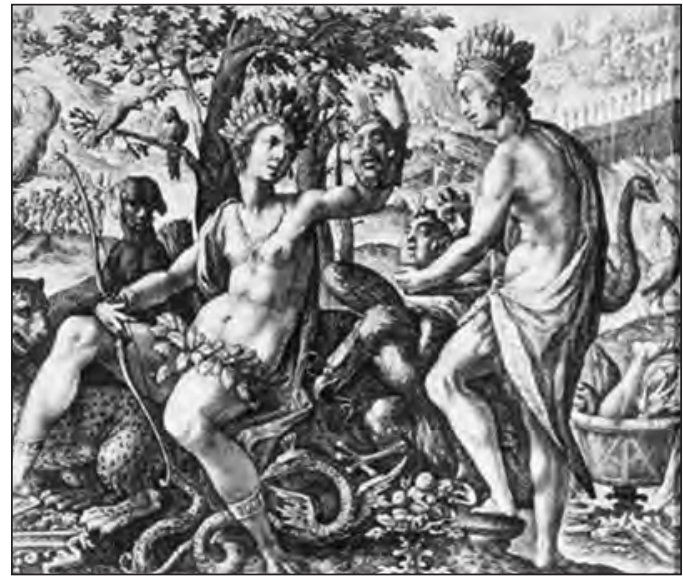

Crispijn van Passe, América (1596).

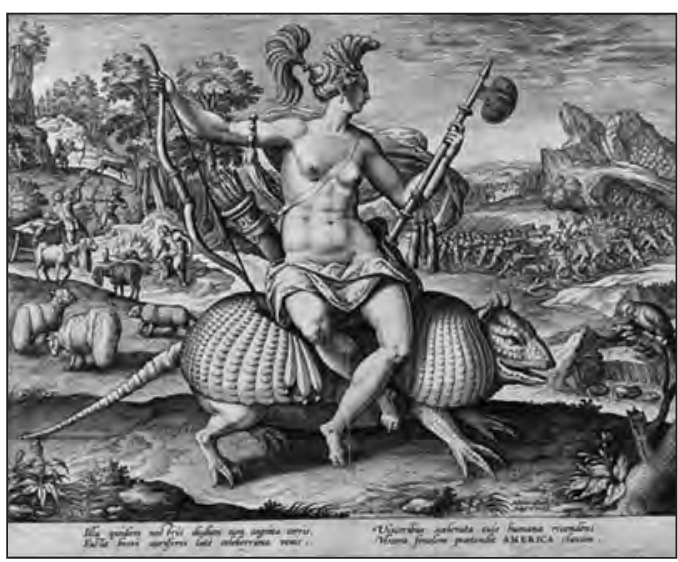

Adrien Collaert, América (1595).

Pero también de esos relatos comienza a emerger la figura simbólica de la amazona americana como mujer aborigen siempre dispuesta a «usos licenciosos», como insistían los cronistas, que casi inmediatamente pasará a reproducir otra dialéctica reconocible: la alternancia entre atracción y rechazo que puede señalarse en el origen del proceso de fetichización del salvaje en la cultura europea moderna, visible también convencionalmente en las alegorías plásticas y cartográficas de América como buena y mala salvaje a la vez (bella amazona de apetitos extremos sobre el hombre europeo, que exhibe su barbarie ambivalente a través de una incitante pero feroz desnudez, montada en un siniestro reptil pero portando en sus brazos el cuerno de la abundancia, o rodeada de paradisíaca vegetación pero también de restos de su banquete erótico-antropófago), que dará origen a un nutrido catálogo, sobre los más diversos soportes, de alegorías de América con atuendo de Amazona, aspecto fiero y rebelde, actitud
8

No se olvide que las Gorgonas - Górgades, según los relatos de Herodoto y Diodoro, eran un pueblo de Amazonas muy temidas que una vez al año realizaban grandes festividades donde los hombres eran invitados, embriagados y extasiados por la belleza aparente de sus anfitrionas, para mantener relaciones sexuales con ellas, tras lo que los contertulios eran asesinados. Dominaban el país de las Hespérides al que llegó Perseo para decapitar a su reina-diosa Medusa, que vivía en un santuario guardado por Euriale, la tercera Gorgona, Ilamada la reina de las Amazonas. Véanse los estudios de Campbell (1955) y Graves (2000), cuyas sugerentes aplicaciones históricas proponen la leyenda de Perseo decapitando a Medusa como una muestra más del dualismo matriarcal/patriarcal y del vencimiento del primero por el segundo, con un fin modélico y modelador para la sociedad y el proceso de adquisición de sus patrones culturales, que se reproduciría con frecuencia también en la América precolombina, según los estudios antropológicos más recientes (cfr. Báez Jorge, 2010)

9

El propio Vespucci se hace eco de ello en su descripción de las prácticas sexuales de las indias: "Otra costumbre tienen tan atroz y fuera de toda credulidad humana: con cierto artificio suyo y la mordedura de ciertos animales venenosos, hacen hinchar los miembros de sus maridos de tal manera gruesa que parecen deformes y brutales, y por esta causa muchos de ellos lo pierden y quedan eunucos» (ibid., 220). Y el mismo fundamento fantasmático parecía tener en el fondo la violencia sexual del relato de Michael da Cuneo a su regreso del segundo viaje de Colón (la primera violación de una india registrada en la cronística americana) dado que, como jus tificación de su 'proeza', explica que su víctima procedía de "una isla grande que está poblada por caníbales» y que las mujeres caníbales «cortan el miembro generativo de los hombres al ras del vientre» (cfr. Gil y Valera 1984, 235).

Androcentrismo, eurocentrismo, retórica colonial: amazonas en América

REMEDIOS MATAIX 
guerrera y cabalgando sobre un armadillo gigante, representante de la fauna americana que se hará habitual en los emblemas europeos, y muy polisémico, pero asociado en principio a la tierra, la feminidad, la astucia diabólica o el carácter guerrero.

Todo eso tiene una sencilla explicación, relacionada tanto con la economía representativa de la alteridad (en femenino) como con la reactivación moderna-colonial del mito clásico de la amazona, para la que la antropofagia, además de ser el signo máximo del salvajismo y el extremo imaginario del miedo masculino al poder 'absorbente' de lo femenino, lo es también del temor al Otro en el espacio de su dominio: representa la contingencia de que esa absoluta otredad desnuda y disponible que se asoció alegóricamente con América fuera a su vez deseante y devoradora. De ahí la necesidad de la 'conquista', término también fuertemente ambivalente, de un espacio erotizado que moviliza un deseo de signo 'masculino' (de penetración, de posesión, de conversión, de dominio). Ésa será la amazona que ingrese en la imaginación hispánica, literaria e iconográfica, de los siglos XVI y XVII. Amazonas en las Indias (1635) de Tirso de Molina ofrece un resumen exacto de todo esto que digo, tras relatarnos la heroína Menalipe las confluencias y divergencias del mito clásico con el indiano (aquí a propósito de la expedición de Gonzalo Pizarro a la provincia de La Canela), y sin que falten los datos sobre Escitia, las conquistas de Asia y Armenia, los nombres de las principales amazonas clásicas y su carácter guerrero, o los encuentros con Hércules, Aquiles y Teseo, pues «Más ha de trecientos siglos/ que de las Scitias remotas/ salieron, dejada Europa,/ a apoderarse de la Asia/ las naciones belicosas/ de cuyos troncos y líneas,/ si no ramos, somos hojas». A todo ello añade Menalipe el paso del tiempo, «el elemento de sal» $y$ «las oceanas ondas» que las llevan hasta tierra americana para establecerse allí junto a un «Gran Río del Pirú» como nuevo Termodonte tropical, combatir contra los españoles «con arcos y aljabas de flechas a las espaldas» (I, 309-524) -pues sus poderes adivinatorios las han hecho sabedoras de sus intenciones de conquista- y convertirse a medida que avanza la acción en personificación perfecta de los contenidos fantasmáticos repasados hasta ahora, incluida la insistencia en que su modo de vida es una inversión, una suerte de antípoda del mundo donde
«Naturaleza/ el orden ha alterado/ que por el orbe todo ha conservado» (I, 45-46). Son fácilmente reconocibles en la definición que ofrece el soldado Caravajal de estas nuevas «comisarias del infierno»: son «...legiones de hembras armadas,/ en los rostros serafinas/ pero en las obras demonios,/pues tanta piedra lloviznan,/ tantos dardos nos arrojan,/ tantos flechazos nos tiran/ que, si no se enamorara/ de la airosa bizarría/ de don Gonzalo Pizarro/ su hermosa reina o cacica,/ y de mí su bruja hermana,/ ipor Dios! que nos desbalijan/ de las almas, y que, hambrientas,/ o nos asan o nos guisan;/ porque comen carne humana/ mejor que nosotros guindas (II, 1483-1498).

Se admite ya por consenso que esa reescritura americana del mito de las amazonas que contribuiría a revitalizar su imagen en las letras hispánicas comienza con su temprana presencia en las Sergas de Esplandián, continuación del ciclo de Amadís de Gaula, publicado en Sevilla en 1511 por Garci Rodríguez de Montalvo, y uno de los libros mas leídos de su época, a uno y otro lado del océano. Parece seguro que el autor recuperaba las noticias de Colón sobre las amazonas americanas para la creación de la ultramarina «ínsula California» (mucho antes de que su territorio real fuera descubierto y bautizado con ese nombre) que es, dice Montalvo, «una cosa la más extraña que nunca por escriptura ni por memoria de gente en ningún caso hallar se pudo»:

Sabed que a la diestra mano de las Indias ovo una isla llamada California mucho llegada a la parte del Paraíso terrenal, la cual fue poblada de mugeres negras sin que algún varón entre ellas oviese, que casi como las amazonas era su estilo de bivir. Estas eran de valientes cuerpos y esforçados y ardientes coraçones y de grandes fuerças. La ínsola en sí, la más fuerte de riscos y bravas peñas que en el mundo se fallava. Las sus armas eran todas de oro, y también las guarniciones de las bestias fieras, en que, después de las aver amansado, cabalgaban; que en toda la isla no había otro metal alguno (...) $\mathrm{E}$ algunas vezes que tenían pazes con sus contrarios mezclávanse con toda segurança unos con otros y avían sus ayuntamientos, de donde seguía quedar muchas dellas preñadas; y si parían hembra guardávanla, y si varón luego era muerto. La causa dello, según se sabía, era porque en sus pensamientos tenían firme de apocar los varones en tan pequeño número que sin trabajo los pudiesen señorear con todas sus tierras, y guardar aquellos que entendiesen que cumplía para que la generación no pereciese (2003, p. 727). 
El topónimo podría derivar de la $\mathrm{Ca}-$ lafonna de los relatos troyanos medievales (Sáinz de la Maza, apud. Montalvo, 2003, p. 22), aunque la ubicación de la fantástica ínsula amazónica amplía el marco espacial caballeresco y parece inspirada por la expectación creada por los nuevos descubrimientos colombinos (Sales Dasí, 1998, pp. 147-153), que proporcionan el contexto adecuado para explicar la aparición de esas amazonas paganas y ultramarinas, tan rentables, como veremos, en términos de evangelización, enriquecimiento y expansión territorial de la Cristiandad: como para el Almirante, la isla femenina de Rodríguez de Montalvo está a mano derecha de las Indias, es la primera que se encuentra partiendo de España, y estaría próxima al Paraíso terrenal. Las moradoras de California, como las de Matinino, tampoco usan del «exercicio femenil», son hábiles guerreras cuyas armas son todas de oro, porque otro metal no se conoce en aquella tierra (otro elemento exclusivo de las Sergas que no figura en las leyendas amazónicas clásicas y sí en la obsesión áurea colombina), y viven separadas del sexo masculino, protegidas por grifos devoradores de hombres. Se trata del reino de la amazona Calafia, «una reina muy grande de cuerpo, muy hermosa para entre ellas, en floreciente edad, valiente en esfuerço y ardid del su bravo coraçón más que ninguna de las que antes della aquel señorío mandaron» (Montalvo, 2003, p. 729). A la llamada del rey de Persia, que quiere arrebatar Constantinopla a los cristianos, y «desseosa en su pensamiento de acabar grandes cosas», Calafia mueve a sus súbditas a participar en la guerra. Su destreza en el mundo de las armas y el deseo de fama mundana genuinamente caballerescos animan a esta hermosa mujer a movilizar todo su ejército femenino en la lucha contra los cristianos. Sus fuerzas se doblegarán, no obstante, ante la irresistible figura de Esplandián y, vencida por las armas y por el amor, la amazona Calafia olvida su tradicional androfobia para abrazar su destino último y ejemplar, que será la sumisión al poder masculino: cae doblemente conquistada por Esplandián, al no poder acceder al amor del héroe (él declara explícitamente que entre las razones por las que no se siente atraído por la reina está la aberración contra natura que detenta la amazona), acepta casarse con quien él escoge para ella, reniega tanto de su indumentaria y costumbres como de su fe pagana y se somete al Orden convirtiéndose al cristianismo, "porque como yo aya visto la orden tan ordenada de vuestra ley, y la gran desorden de las otras, muy bien claro se me muestra ser por vosotros seguida la verdad y por nosotras la mentira y falsedad». Así, no sólo es que el temible enemigo se convierte en el decisivo aliado que permite la salvación de Constantinopla, sino que la alteridad de Calafia queda neutralizada a través de la redención de su «doble pecado»: la diferencia religiosa y un comportamiento contra la naturaleza propia de su género.

Como permite afirmar la crítica reciente, estas amazonas, 'antípodas', valientes, esforzadas y al fin inevitablemente conversas, que pasan de oponente a auxiliar del héroe y cuya fortuna como tipo recurrente en la narrativa caballeresca es enorme (Taufer, 1991, pp. 35-51), apoyan «el giro ideológico que con Esplandián aparta a la caballería de su autocontemplación aristocrática y galante, y convierte a su héroe en promotor de una nueva caballería cristiana universal, según el canon de situaciones interlocutivas consagrado en el género", contribuyen al nuevo modelo de caballería que se erige en la transición del mundo medieval al renacentista asumiendo una idea de Cruzada que, frente a las vanaglorias terrestres, tiene como propósito promover la fe cristiana a costa del paganismo (Giráldez, 1994, pp. 183-196), y -precisamente por todo eso- refuerzan la adaptación del género caballeresco (en las dos isotopías fundamentales que lo rigen, la bélica y la amorosa) a la ideología providencialista y mesiánica propia de la empresa conquistadora cristiana del Mediterráneo y las Indias, con un sentido colectivo de la acción bélica perfectamente aplicable a esa nueva Gran Conquista de Ultramar que se inaugura en 1492. En otras palabras: ya desde esa primera revitalización literaria, el mito amazónico (pese a su transgresión inherente) fue útil como instrumento de la propaganda imperial en tanto que pudo subordinarse a la ideología cristiana, patriarcal y colonial que apoya la noción imperial de conquista de las Indias en el marco de la concepción mesiánica y utópica del imperio español, y en tanto que pudo reconvertirse al nuevo imaginario que se desarrolla al mismo tiempo que el avance por tierras americanas; un imaginario que se fundamenta -además de en la superioridad de los españoles y la inferioridad de los pueblos indígenas- en los grandes móviles de la empresa: el oro metafórico de la salvación de
Androcentrismo, eurocentrismo,
retórica colonial: amazonas en América

REMEDIOS MATAIX 
las almas y el oro y las riquezas como valores económicos reales, como sugiere la California de Esplandián, como apuntaban los textos de Colón y como apuntarían también otros muchísimos ejemplos, porque ese renovado arquetipo de amazona americana, con perfiles prácticamente idénticos a los de esos textos fundacionales, subsistirá operativo todo el tiempo que tarden los europeos en esparcirse por el continente. Principalmente en tres puntos más de la geografía americana además de las Antillas colombinas: México (lo que se llamó la Nueva Galicia), la provincia de Los Llanos en el Nuevo Reino de Granada (Colombia-Venezuela) y la región selvática que llevaría su nombre, compartida hoy entre Colombia, Perú y Brasil, aunque también Antonio Pigafetta, el cronista de la expedición de Magallanes, informará en 1522 de una isla «llamada Occoloro, bajo Java Mayor, donde sólo viven mujeres. Las fecunda el viento y después, al parir, si lo que nace es macho, lo matan; si es hembra, la crían. Si desembarcan en aquella isla hombres, mátanlos también en cuanto les es posible» (1941, p. 153).

Cronológicamente, después de las amazonas de Colón (y de Rodríguez de Montalvo), la siguiente mención del mito autóctono tiene lugar en 1518. Juan de Grijalva recorre las costas de Yucatán (entonces creída isla), preparando la penetración en tierra firme que culminará Hernán Cortés con la conquista de México, y el clérigo Juan Díaz, uno de los expedicionarios, escribe la relación del viaje y anota en ella que «encontramos una muy hermosa torre en una punta, la que se dice ser habitada por mujeres que viven sin hombres; créese que serán de raza de amazonas». El pasaje lo recoge textualmente Fernández de Oviedo (libro XXXIV, cap. VIII), y el mismo cronista proporciona otro texto mucho más extenso sobre el lugar llamado Ciguatán, que, según él, «en aquella lengua desa provincia (se refiere a Nueva Galicia) quiere decir pueblo de mujeres». Se trata del relato de la expedición de Cristóbal de Oñate alrededor de 1533, quien, habiendo tenido noticias de que el País de las Amazonas estaba situado en las cercanías del río Ciguatlán o «Río de las $\mathrm{Mu}$ geres» (el río San Lorenzo), pidió a Nuño de Guzmán, gobernador de Nueva Galicia, «le hiciese merced de aquella empresa e pacificación de aquellas amazonas» que «son ricas y temidas». Muerto Oñate en un encuentro con los indios de Quínola, prosiguió la expedición el capitán Gonzalo López, quien -nos cuenta Oviedo- llegó a tener contacto directo con aquellas mujeres, pues «llevaron a su pueblo a los españoles, diéronles muy bien de comer e todo lo necesario de lo que ellos tenían necesidad»:

Aquel pueblo es de hasta mill casas, e muy bien edificado, e las calles en gentil concierto, e asentado en lo mejor de la tierra e más fértil e apacible. E queriendo los españoles inquirir el modo de vivir de esas mujeres, súpose de ellas mesmas que todos los mancebos de aquella comarca vienen a aquella población de las mujeres cuatro meses del año a dormir con ellas, y ellas se casan con ellos de prestado por aquel tiempo, e no más, sin se ocupar ellos en más de las servir e contentar en lo que ellas les mandan que hagan de dia en el pueblo o en el campo, y en cualquier género de servicio que ellas los quieren ocupar de día, e de noches dales sus propias personas e camas. $Y$ en este tiempo cultivan e labran e siembran la tierra e los maizales y legumbres, e lo cogen e ponen dentro en las casas donde ellos han seido hospedados; e cumplido aquel tiempo que es dicho todos ellos se van e tornan a sus tierras donde son naturales. E si ellas quedan preñadas, después que han parido, envían los hijos a los padres, para que los críen e hagan dellos lo que les pluguiere, después que ha dos o tres meses o antes; e si paren hijas, retiénenlas consigo e crianlas para la aumentación de la república suya (Oviedo, 2007, p. 283).

Naturalmente, también «vieron los españoles entre aquellas mujeres turquesas y esmeraldas, e decíanles que había destas dos maneras de piedras presciosas mucha cantidad e muy buena», lo que explica que incluso Hernán Cortés - pese a su pragmatismo tan poco proclive a ensoñaciones míticas- diera crédito a tantos relatos (a los citados hay que sumar los de su teniente Cristóbal de Olid sobre la parte oeste de la Nueva España y los de sus capitanes Gonzalo de Sandoval y Francisco Cortés de Buenaventura que habían consumado entre 1522 y 1524 la conquista de la provincia de Colima) sobre la existencia del país poblado sólo por mujeres «las quales diz que tienen en la generación aquella manera que en las historias antiguas describen que tenían las amazonas», hasta el punto de incluirlas en las Instrucciones (1524) dadas a sus lugartenientes (apud. Cárdenas, Pacheco y Torres de Mendoza, 1864-1894, vol. 26, p. $153)$, probablemente tanto para «saber la verdad desto e de lo demás y hacer de ello larga 
relación a vuestra Majestad», como porque «muchos de esta provincia (...) dícenme asimismo que es muy rica de perlas y oro", como revelara su Cuarta Carta de Relación a Carlos V (Cortés, 1963, pp. 368-370).

Por otra parte, según el relato del Inca Garcilaso de la Vega, tampoco faltaron tribus con cacicas al mando en la expedición de Hernando de Soto a La Florida (1539-1543), como la de la Señora de Cofachiqui, que trató muy de cerca con los españoles, ni mujeres guerreras «que peleasen con la misma ferocidad que los varones", cinco de las cuales - casi como las indias de Vespucci- atacaron a Francisco de Reynoso Cabeza de Vaca en Tula y lo vencieron «haciéndolo presa del [órgano] viril a bocados y puñadas» (2009, III, 28 y IV, pp. 10-12). Cuando fracasaron los intentos de localizar al Norte del hemisferio a aquellas mujeres tan ricas e independientes como inalcanzables, se las buscó al Sur. La épica marcha del Licenciado Jiménez de Quesada desde Santa Marta a la sabana de Bogotá (1535-1536) inaugura nuevas pistas sobre ellas, pese a que el objetivo era El Dorado, no las Amazonas. Pero Juan de San Martín y Alonso de Lebrija, en su Relación del descubrimiento y conquista del Nuevo Reino de Granada (1536-1539), estuvieron a apenas cuatro jornadas del país de las mujeres y llegaron a averiguar mucho más. Su descripción se ajusta a lo dicho hasta entonces, salvo el matiz de que «se sirven de hombres esclavos hasta empreñarse dellos» (apud. Oviedo, 2007, p. 362), lo que les hará responsables de propagar la noticia en España de que diez millares de tales amazonas habían desembarcado en Santander para esclavizar a los españoles, procrear con ellos y llevarse a las hijas (Leonard, 1954, p. 62).

De nuevo en Suramérica, las amazonas reaparecen, ubicuas, en casi todas las expediciones que partieron a la búsqueda de El Dorado, en una progresión creciente con respecto a la promesa de sus riquezas ( Tienen oro, encima de la tierra, en joyas, y debajo de la tierra lo sacan de minas. Esto es lo que se pudo saber destas mujeres», resume Fernández de Oviedo tras la recopilación de los múltiples relatos) y -tampoco por casualidad- «siempre en zonas marginales a las altas culturas maya, azteca, inca, o culturas medias como la chibcha, todas ellas de régimen patriarcal», como subraya Lola G. Luna (1982, p. 305): son vistas en los Llanos venezolanos por Jerónimo Dortal, en las márgenes del río Meta según Jorge de Espira y en las del Santa Marta según Hernán Pérez, en las llanuras inundadas del Paraguay que recorrió Hernando de Ribera, en Brasil por Manoel da Lóbrega y Joáo de Azpilcueta, en Chile por Pedro de Valdivia y Agustín de Zárate, y en Argentina por Ulrich Schmidl, cuya Verídica historia de una nave-

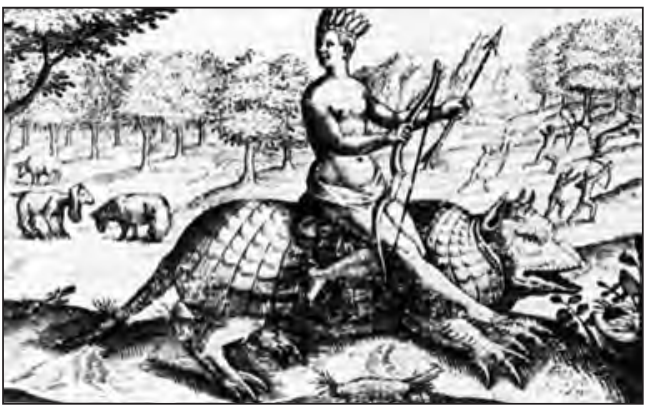

Ilustración de Levinus Hulsius para Ulrich Schmidl, Verídica historia... (1599). gación maravillosa llevada a cabo en América o Nuevo Mundo en el Brasil y el Río de la Plata (1567) fue incansablemente reeditada acompañada de ilustraciones y frontispicios alusivos a esas omnipresentes amazonas autóctonas.

La lista podría continuar, porque buena parte de las crónicas de los dos primeros siglos de colonización confirmarán las noticias de esa nación femenina en diversos lugares del nuevo continente, y sus ecos se difundirán en cuantas Geografías, Descripciones, cartografías e Historias Generales o Naturales de las Indias se publicaron durante los siglos XVI y XVII. Y después de los conquistadores partirán en busca de las amazonas los misioneros, para bautizarlas y evangelizarlas: todavía en 1737, el padre Pablo Maroni abría su Societatis Iesu con el capitulo "Examínase si ha habido o hay, al presente, Amazonas» en la región del Marañón, «porque es común voz en todas estas provincias que las hay», y recogía cuantos testimonios de misioneros pudo recopilar acerca de aquellas «mujeres belicosas que se gobiernan por sí solas, sin más comercio con los hombres que el preciso para el aumento de su república» (apud. Tobar Donoso, 2004, pp. 116 y ss).

Pero entre todos los relatos sobre la cuestión existen algunos excepcionales, no sólo porque la aclimatación del mito adquiera mayor verosimilitud historiográfica, sino además porque hacen evidente su inserción en esa retórica colonial de la que hablamos, por la que la presencia, ferocidad y voracidad de las amazonas era directamente proporcional a la resistencia que ofrecía el terreno frente al apetito evangelizador, conquistador o comercial, pues no era posible mayor 'salvajismo' que no querer trato o comercio con tal misión civilizadora. Se trata de los testimonios directos de quienes dijeron verlas y combatirlas: el primero, el del dominico Gaspar de Carvajal
Androcentrismo, eurocentrismo, retórica colonial: amazonas en América

REMEDIOS MATAIX 


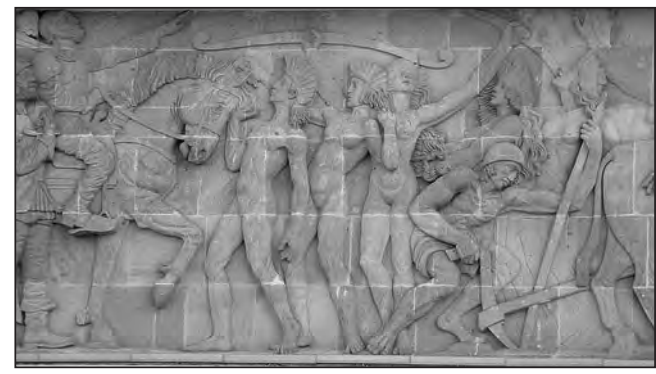

"Orellana y las amazonas (o icamiabas)», friso de Luis $\mathrm{Mi}$ deros (1920).

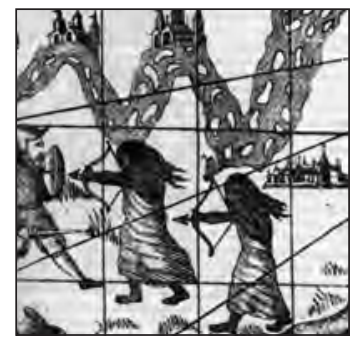

Sebastián Caboto, Mapamundi (1544; detalle).
Androcentrismo, eurocentrismo, retórica colonial: amazonas en América

REMEDIOS MATAIX en su Relación del descubrimiento del río Grande de las Amazonas por Francisco de Orellana, compuesta hacia 1541. A diferencia de las amazonas griegas, las de Fray Gaspar «no se cortan la teta derecha, como lo hacían las de los antiguos» y son «mujeres muy bellas, muy blancas [quizá por contraste con las amazonas negras de Montalvo que tal vez esperaba encontrar], muy altas y con muy largo el cabello y revuelto a la cabeza; muy membrudas y andan desnudas en cueros, con sus arcos y flechas en las manos, haciendo tanta guerra como diez indios». No están enteramente dedicadas al arte de la guerra ni viven en un estadio cultural 'primitivo': habitan en setenta pueblos con casas de piedra, con una compleja organización social reflejada en su vida urbana, y lejos de ignorar la agricultura (como sus pares del viejo mundo), poseen grandes labrantíos que producen abundantes alimentos. Tienen una organización política de tipo monárquico, respondiendo a la jefatura de una de ellas que se llama Coñori, y en sus recintos sagrados (Casas del Sol) se depositan fabulosos tesoros, pues eran «señoras de mucho metal» y hasta «las ataderas con que hacían sus casas eran de oro», y tienen muchas provincias e indios vasallos que son sus servidores y protegidos y les pagan tributos. «Cuando les viene aquella gana -continúa Carvajal- hacen la guerra a un señor vecino y traen indios prisioneros a su país. Los guardan el tiempo que se les antoja. Cuando se sienten preñadas los envían de vuelta sin hacerles ningún mal. Si paren hijo le matan o le envían con sus padres, si hija la crían con solemnidad y la imponen en cosas de la guerra» (Carvajal, 2007).

Las primeras noticias sobre tal nación femenina las recibe la expedición al aproximarse a la confluencia del Tefe con el Marañón. Fray Gaspar anota que los indios le dijeron que «íbamos a ver los amurianos que en su lengua llaman coniupuyara, que quiere decir grandes señoras, que mirásemos lo que hacíamos, que éramos pocos y ellas muchas, que nos matarían; que no estuviésemos en su tierra». Días después, mientras navegan cerca de la orilla en busca de un sitio para detenerse, entran en contacto con esas mujeres guerreras: divisan un pueblo, Orellana ordena que los bergan- tines se aproximen a la ribera para apropiarse de alimentos y los indios resisten con tal bravura y disparando tantas flechas que los españoles no logran defenderse y remar al mismo tiempo. Antes de alcanzar tierra ya había cinco heridos, el cronista Carvajal entre ellos. En la orilla continúa el combate cuerpo a cuerpo durante horas y cuando Orellana ve aproximarse refuerzos indios, ordena apresuradamente la retirada, entre una flota de canoas que los persiguen y que a duras penas consiguen esquivar. Tal resistencia, explica Fray Gaspar, se debe a la presencia de las amazonas, porque «estos indios (...) son subjetos y tributarios a las amazonas, y sabida nuestra venida, vánles a pedir socorro y vinieron hasta diez o doce, que éstas vimos nosotros, que andaban peleando delante de todos los indios como capitanas, y peleaban ellas tan animosamente que los indios no osaron volver las espaldas, y al que las volvía delante de nosotros le mataban a palos, y ésta es la cabsa por donde los indios se defendían tanto» (ibid.).

Dos años después de que la expedición alcanzara el Atlántico y partiera a España en busca del apoyo para una nueva incursión en la zona, esta vez equipada con artillería, Sebastián Caboto diseña el primer mapamundi en que aparece todo el «Río de las Amazonas que descubrió Francisco de Orellana» y en el lugar donde se libró el combate narrado por Carvajal dibuja mujeres indias disparando con arcos y flechas contra los españoles: la leyenda geográfica se concretaba en la geografía real, y desde entonces todas las relaciones de las siguientes expediciones que descendieron o remontaron el Río Grande de las Amazonas confirmarán las noticias sobre aquella nación femenina.

Hay otros tres testigos de vista excepcionales de ésas u otras amazonas americanas y simbólicas de los rasgos que nos interesan: desde 1555 habla de ellas un gran intelectual de la época, el francés André Thévet, Cosmographe du Roi, quien había viajado a América al amparo de los intentos (frustrados) de Henri II por establecer una colonia francesa en la bahía de Río de Janeiro. Tanto en Les singularités de la France Antarctique autrement nommée Amèrique (1557), el primer tratado sobre América en francés, como en Cosmographie Universelle (1575), describe lugares, productos, flora y fauna, así como a los habitantes de aquellas tierras, sus formas de vida y costumbres alimenticias, con rasgos en 
buena medida tópicos del salvaje cristiano (la irracionalidad, la idolatría y los tratos con el demonio), a los que se suman las costumbres sexuales licenciosas y de apetito irrestricto, los sacrificios humanos y el canibalismo. Sus detalladas descripciones las corroboraban los abundantes grabados de Jean Cousin con que se acompañó la edición, muchos de ellos dedicados a las amazonas, a las que Thévet consagra un capítulo entero y de las que dice que «vivían exactamente como vivieron, según lo que sabemos, las Amazonas de Asia» que después de la guerra de Troya se dispersaron por el mundo. En América, explica Thévet, se las encuentra en islas y viven en pequeñas habitaciones o en cavernas. Sus enemigos las hostigan continuamente y ellas se defienden con amenazas, aullidos y gestos horrorosos, parapetadas detrás de caparazones de grandes tortugas. Dan un trato inhumano a sus prisioneros: para darles muerte los cuelgan de una pierna a la rama de un árbol y al cabo de un tiempo, si el desafortunado aún está con vida, le disparan diez mil flechas y encienden una hoguera para cocinarlo y comérselo (Thévet, 1983, pp. 163-168).

También Walter Raleigh, favorito de la reina Isabel de Inglaterra luego caído en desgracia tras la ruinosa fundación de Virginia en 1585 (primera colonia inglesa en América del Norte, desaparecida tres años después), ofreció notables noticias sobre las amazonas en el relato de la también frustrada expedición a la «ciudad dorada de Manoa». En 1596 vio la luz en Londres su libro The Discoverie of the Large, Rich, and Bewtiful Empyre of Guiana y la obra pronto se hizo tan popular que no tardó en ser traducida, al holandés, al alemán y al latín, en las versiones ilustradas de Levinus Hulsius (1599) y en la famosa América de Théodore de Bry (vol. VIII, publicado en 1599), con especial hincapié en el gran festín erótico anual de las amazonas del que hablaba el cronista, en el que las mujeres «libres de odios y con grandes deseos» se juntan con los hombres -al estilo del Paraíso de El Bosco o de la Aurea Aetas de Lucas Cranach-, entre «banquetes, bailes y vino en abundancia» (Raleigh, 1986, pp. 178-179).

Con estos relatos textuales e iconográficos la imagen de la amazona americana reforzaba su inserción cultural y etnográfica, además de su asociación en el imaginario colectivo al ambivalente atractivo de un Nuevo Mundo oscilante entre lo siniestro y lo paradisíaco, pero aún en 1641, un siglo



Levinus Hulsius, "La isla de las Amazonas», para Walter Raleigh, Brevis et admiranda descriptio regni Guianae (1599).

después de la expedición de Orellana, la de Pedro Teixeira relatada por Cristóbal de Acuña en el Nuevo descubrimiento del gran río de las Amazonas despejaba toda duda residual (pues «los fundamentos que hay para asegurar provincia de Amazonas en este río son tantos y tan fuertes, que sería faltar a la fe humana no darles crédito») y añadía nuevas informaciones sobre los 'métodos de seducción' que esas mujeres practicaban sobre sus hamacas que tendrían enorme fortuna imaginaria (Acuña, 2009, p. 54).

De la mano de esos relatos, y especialmente de sus ediciones ilustradas, la amazona americana consolidó definitivamente su impacto sobre el imaginario occidental a ambos lados del océano. Desde la orilla americana, a Juan de Castellanos el renacimiento del mito le pareció «novela liviana» o «fantasía superchera», aunque no perdió ocasión de recrear cuantas historias de esas «mujeres sueltas y flecheras,/ con fama de grandisimas guerreras» adornan las vidas y expediciones cantadas en sus Elegias de varones ilustres de Indias (ca. 1589), en especial para subrayar su belleza y su amplia predisposición amorosa para con los cristianos: «Lindos ojos y cejas, lisas frentes,/ gentil dispusición, belleza rara,/ los miembros todos claros y patentes,/ porque ningún vestido los repara» y porque «de sus consorcios y congregaciones/ fea, contrahecha, manca se destierra». "No quieren compañía de varones -continúa-/ ni jamás los consienten en su tierra,/ mas gozan en sus tiempos y sazones/ de aquellos con quien ellas tienen guerra,/ y entre tanto dura la lujuria,/ con ellos cesa la guerrera furia». Orocomay, por ejemplo, además de ser «hermosa, varonil, cabal,/ en todas proporciones elegante,/ y para guerra y paz

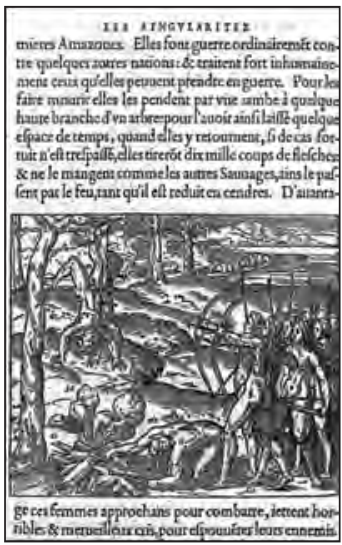

Las Amazonas americanas. André Thévet, Les singularités de la France antarctique (1557).

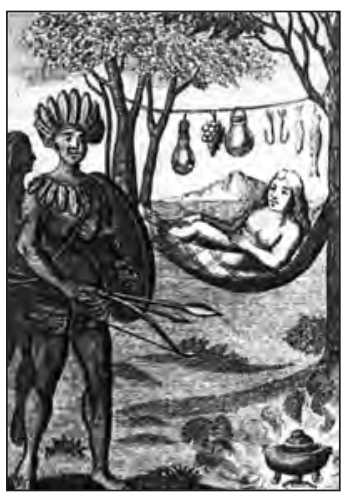

Amazona seduciendo a un indio desde su hamaca, según el ritual descrito por Cristóbal de Acuña (edición holandesa de la Relación de Acuña, 1717).

Androcentrismo, eurocentrismo, retórica colonial: amazonas en América

REMEDIOS MATAIX 
mujer bastante», es «Señora de grandísimo talento,/ y á cualquier español aficionada», pues «en general es este mujeriego/ de bien compuestos miembros y lozanos,/ ninguna cosa duras al entrego:/ que suelen recibir lascivas manos/ derretidas en amoroso fuego,/ grandes aficionadas a cristianos» (2007, Elegías II, III, IV y XIV, tomo I). Lejos han quedado ya las tradicionales virilidad y androfobia, e incluso los llamados «matrimonios de visita»; y esa insistencia en afirmar la feminidad de las amazonas, en destacar su belleza y su disposición abierta a ofrecerse pródiga al intercambio con los extraños conduce, en confluencia con otras configuraciones imaginarias coloniales de las que estamos hablando, a otras cristalizaciones ideológicas muy significativas, como la que (sugerida ya en el Theatrum Orbis Terrarum) está en la base de otra tesis ampliamente difundida en la crónica y la historia de América, que apunta al fundamento mismo del ser hispanoamericano y se desenvuelve simultáneamente en dos niveles: el erótico y el cultural. $\mathrm{Me}$ refiero al mestizaje y a los estereotipos o mitos construidos a su alrededor casi desde el inicio mismo del proceso de conquista y colonización; unos mitos casi siempre de doble lectura (el mestizaje y la construcción de la nueva cultura por un lado, el «Malinchismo», la violencia y la orfandad o bastardía originales por otro), pero que, para lo que nos interesa ahora, sostienen la idea de que ese mestizaje -y con él la construcción de la nueva cultura-fue posible gracias a la supuesta incitación o receptividad de la mujer indígena para el «abrazo amoroso» con un conquistador que además se presenta en el imaginario compartido de la época como el portador de la luz civilizadora, de la Verdad y la Salvación, de modo que la entrega sexual de la amazona autóctona, ya nada andrófoba, significaría para ella la vía de acceso a un doble goce, corporal y trascendente, disfrutado en brazos de quien la haría empezar a existir ontológicamente en la Historia. Esa proposición, implícita en la mayor parte de los cronistas -y en no pocos estudiosos contemporáneos-, junto a la recurrente desnudez cronística e iconográfica de América, tuvo como consecuencia imaginaria (además de exculpar a la conquista de los actos de violación, individual o colectiva, perpetrados contra la mujer india) la casi instantánea identificación del Nuevo Mundo con una especie de materialización sexual del País de Jauja, lo que constituye «la principal aportación americana al motivo literario tradicio- nal» de esa tierra imaginaria caracterizada por la abundancia y la gratuidad de alimentos, la ociosidad, la juventud eterna y el completo bienestar social (Herrero, 1941). Lo ilustran bien innumerables pasajes de las crónicas en los que se comenta la facilidad de las indias para entregarse a los españoles, muchos romances y letrillas populares que contaban las historias de Ultramar bajo la forma de una Tierra de Jauja «cuyos grandiosos espacios/ o son pensiles de $\mathrm{Baco} /$ o son jardines de Venus» (ibid., p. 154) o el famoso «Passo quinto» de El Deleitoso (o Paso de la Tierra de Janja), de Lope de Rueda, considerado la primera reelaboración de un tema que será frecuente en la poesía y la dramaturgia españolas de los Siglos de Oro y que estimuló la imaginación de sus principales ingenios.

En esa América-Jauja sexual, otro buen reclamo propagandístico para estimular el viaje transatlántico, no podía suponerse que pasara otra cosa que la desenfrenada posesión de las indias -fuera consentida o no- por parte de unos conquistadores a los que desde antes de partir se autorizaba a tomar por suyo cuanto encontraran. De ahí los numerosos episodios de amoríos entre españoles e indias (algunos francamente eróticos) de la literatura y el teatro barrocos, que atribuyen -como hace el Arana de Lope de Vega en El Nuevo Mundo descubierto por Cristóbal Colón-la «facilidad» de las mujeres indígenas al hábito de vivir desnudas: «Por deshonra tienen éstas/ el negar la voluntad;/ que del no vestirse honestas/ les nace la enfermedad» $(1980$, p. 35). Es el rasgo que completa la imagen estereotipada de las amazonas americanas que pueblan los textos literarios españoles desde entonces (por una parte, mujeres hostiles y vengativas; por otra, glotonas libidinosas), a menudo con una interesante adaptación del mito a los esquemas cortesano-amorosos y caballerescos que permite rastrear el arquetipo de la 'mujer difícil' con rasgos amazónicos y ultramarinos más allá del corpus explícitamente indiano y catalogado tradicionalmente como tal. El mismo Lope de Vega revela esa dilatada filiación en el prólogo de Las mujeres sin hombres:

...Yo las hallo en Virgilio y en todos los autores y no sólo en aquellos, sino tan cerca de nuestra edad que en el viaje de Magallanes fueron vistas, si no mienten las relaciones de Sebastián del Cano y de Gonzálo de Oviedo [sic]; y aún he oído decir que andan algunas entre nosotros, como son viudas mal acondicionadas, 
suegras terribles y doncellas insaciables, que todas estas son Amazonas o vienen de ellas (1916, VII-VIII).

En definitiva, si para el mundo clásico las Amazonas y su matriarcado constituían un contrapeso a sus valores patriarcales esenciales o fundantes, la representación del caos original siempre acechante frente al orden que él encarnaba, y por cuya lógica simbólica podía pensarse los polos de esa disyuntiva, en la imaginación hispánica de los Siglos de Oro constituyen una modalidad de personajes que, sin dejar de representar esa amenaza para el orden y la civilización androcéntrica por sus múltiples signos de alteridad (lo femenino, lo bárbaro, lo salvaje), encarnan un mito muy interesante por poliédrico, ya que suman al rasgo inversor por el que la mujer-alteridad ha de ser combatida y conquistada para instituir el orden, la capacidad de emblematizar la contraposición con el Otro americano -difícil de aceptar en cuanto tal, y, por tanto, transformado según los casos en enemigo al que combatir, en salvaje al que domesticar y reconducir al propio horizonte cultural o, incluso, en monstruo no humano al que eliminar-, y sirven además para consolidar las prerrogativas y los esencialismos de los discursos oficiales con un valor simbólico asociado redundante con el discurso colonial sobre la conquista de América como una empresa heroica y viril de expansión de la 'civilización' del Imperio cristiano español al que todos los autores de la época (peninsulares y virreinales) se acogieron. De ahí la importancia de doblegarlas, pues su derrota o su entrega constituyen la reafirmación de la concepción providencialista del descubrimiento, homogeneizadora, vertical, jerárquica y patriarcal, a la que los argumentos literarios corresponden punto por punto, pese a que a veces la relación de vasallaje doctrinario se transforme en el principio cortesano de dominación amorosa o en la puesta en práctica de la máxima virgiliana Omnia vincit Amor a través de la metamorfosis poética de la mujer belicosa en mujer enamorada y dócil. Que la mayoría de relatos en que participa este arquetipo de mujer libre acabe mostrando su derrota militar, su total entrega amorosa, su deseo de inserción en la sociedad del conquistador y hasta en la Corte, cuando no su muerte, así lo certifica. Es de nuevo Tirso de Molina quien hace resumir a su amazona Menalipe, dirigiéndose a Pizarro, todo esto que digo:

\author{
Admíteme por tu esposa; \\ derogaranse mis Leyes, \\ juzgaranse venturosas \\ a tus pies estas provincias. \\ Diamantes que al sol se opongan \\ te rendirán estos cerros, \\ perlas el mar de sus conchas, \\ a montes la plata pura, \\ el oro a cargas que brotan \\ esos ríos, esas fuentes, \\ esmeraldas, plumas, aromas, \\ y un alma nunca rendida, \\ que dueño te reconozca (I, 586-598).
}

Ejemplos como los mencionados parecen confirmar que lo que pareciera ser a simple vista un mosaico de retazos del archivo clásico y medieval europeo, tal vez tiene más que ver con la Modernidad colonial, evangelizadora, comerciante y expansiva. La Conquista se alegoriza como un encuentro sensual entre el hombre, depositario del poder, del orden, de la civilización y de la verdad, y todas esas variantes hispánicas de la amazona «deseosa de ayuntarse con los cristianos", que son, sin duda, construcciones masculinas de la alteridad femenina como lugar de dominio ilimitado aunque no siempre dócil, pero quizá sean también un tropo de la invención-dominación de América determinante en un imaginario colectivo inseparable de esa experiencia histórica, que ilustra bien las oposiciones binarias que hemos ido señalando como articuladoras de la retórica colonial. La revitalización del mito amazónico a partir de los acontecimientos de 1492, pues, no fue sólo la mera repetición crédula del archivo mítico previo, sino la construcción de una nueva imagen detrás de la cual encontramos la consolidación de la ideología imperialista, colonial y mercantilista, y las tensiones discursivas e imaginarias que produjeron sobre la conciencia androcéntrica y eurocéntrica occidental la expansión territorial y el miedo a los signos de resistencia autóctonos.

\section{Bibliografía}

Acuña, Cristóbal de (2009), Nuevo descubrimiento del Gran Río de las Amazonas, ed. de Ignacio Arellano, José María Díez Borque y Gonzalo Santonja, Madrid, Iberoamericana-Vervuert.

Alonso del Real, Carlos (1965), «Geografía de las Amazonas», Cuadernos Hispánicos, núm. 183 (1965), pp. 473-485.

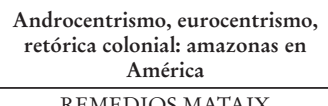

REMEDIOS MATAIX 
- (1967), Realidad y leyenda de las amazonas, Madrid, Espasa Calpe.

Apolodoro (1985), Biblioteca Mitológica, trad. y notas de M. Rodríguez de Sepúlveda, Madrid, Gredos.

Asensio, Eugenio (1949), «La carta de Gonzalo Fernández de Oviedo al Cardenal Bembo sobre la navegación del Amazonas», Revista de Indias, núm. 9 (1949), pp. 1-38.

Báez Jorge, Félix (2010), «La vagina dentada en la mitología de mesoamérica: itinerario analítico", Revista de Antropología Experimental, núm. 10 (2010), pp. 25-33.

Blok, Josine H. (1995), The Early Amazons: Modern and Ancient Perspectives on a Persistent Myth, Leiden, Brill.

Campbell, Joseph (2005), El héroe de las mil caras: psicoanálisis del mito (1959), México, FCE.

Cárdenas, Francisco de, Pacheco, Joaquín Francisco y Torres de Mendoza, Luis (comps.), 1894, Colección de documentos inéditos relativos al descubrimiento, conquista y organización de las antiguas posesiones de América y Oceanía, sacados de los archivos del reino y muy especialmente del de Indias, Madrid, Ministerio de Ultramar, 1864-1894. Disponible en www. archive.org, de donde cito.

Carmona Fernández, Fernando (1993), «Conquistadores, utopías y libros de caballería», Revista de filología románica, núm. 10 (1993), pp. 11-30.

Carranza Aguilar, María Eugenia (2000), Antropología y Género. Breve revisión de algunas ideas antropológicas sobre las mujeres, Valladolid, Servicio de Publicaciones de la Universidad de Valladolid.

Carvajal, Gaspar de (2007), Descubrimiento del río de las Amazonas, ed. digital de la Biblioteca Virtual Miguel de Cervantes, Alicante, 2007, sobre la de Bogotá, Prensas de la Biblioteca Nacional, 1942.

Castellanos, Juan de (2007), Elegías de varones ilustres de Indias compuestas por Juan Castellanos, ed. facsímil digital de la Biblioteca Virtual Miguel de Cervantes, Alicante, 2007, sobre la de Caracas, Parra León Hermanos, 1930.

Colón, Cristóbal (1984), Profecías que juntó el Almirante Don Christóval Colón de la Recuperación de la Santa Ciudad de Hierusalém y del descubrimiento de las Indias, dirigidas a los Reies Cathólicos, ed. facsímil a cargo de F. Álvárez Seisdedos, Madrid, Testimonio.

- (1987), El libro de Marco Polo anotado por Cristóbal Colón, ed. de Juan Gil, Madrid, Alianza Editorial.

- (1989), Textos y documentos completos, ed. de Consuelo Varela, Madrid, Alianza Editorial.

Cortés, Hernán (1963), Cartas y documentos, ed. de Mario Hernández Sánchez-Barba, México, Porrúa.

De la Vega, Inca Garcilaso (2009), La Florida del Ynca: historia del adelantado Hernando de Soto, Gouernador y capitan general del Reyno de la Florida, y de otros beroicos canalleros españoles è indios ed. facsímil digital de la Biblioteca Virtual Miguel de Cervantes, Alicante, 2009, sobre la de Lisboa, Pedro Crasbeeck, 1605.

Diago Marco, Marta (2009), «Justificando el orden establecido: las amazonas, un mito masculinizador», en Arqueólogos (www. arqueologos.org), núm. 62 (2009).

Fernández de Oviedo, Gonzalo (2007), Historia general y natural de las Indias, islas y Tierra Firme del Mar Océano, edición digital de la Biblioteca Virtual Miguel de Cervantes, Alicante, 2007, sobre la de Madrid, Real Academia de la Historia, 1851.

García Sanz, Óscar (1998), «Amazonas: una realidad histórica para la tradición occidental y la del nuevo mundo», en Analecta Malacitana, XXI, núm. 2 (1998), pp. 609-622.

Giráldez, Susan (1994), «Las Sergas de Esplandián, Granada, Constantinopla y América: la novela caballeresca como portavoz de la modernidad», en JA. Fernández Roca, C. Gómez Blanco y JM. Paz Gago (coords.), Semiótica y modernidad. Actas del $V$ Congreso Internacional de la Asociación Española de Semiótica, A Coruña, Universidade, Vol. 2, pp. 183-196.

González Boixo, José Carlos (1996), «El mito de las amazonas», en $\mathrm{M}^{\text {a }}$ Antonieta Gallegos Ruiz y Alfonso González (eds.), Ensayos de descubrimiento y colonia, Toluca, México, Universidad Autónoma del Estado de México.

Gil, Juan y Varela, Consuelo (eds.), 1984, Cartas de particulares a Colón y Relaciones coetáneas, Madrid, Alianza.

González de Clavijo, Ruy (2004), Vida y hazañas del Gran Tamerlán, con la descripción de las tierras de su imperio y señorio, 
edición digital de la Biblioteca Virtual Miguel de Cervantes, 2004, sobre la de Madrid, Miraguano, 1984.

Graves, Robert (2000), Dioses y héroes de la antigua Grecia, Barcelona, Lumen, 2000.

- (2004), Los mitos griegos, Barcelona, Ariel.

Harris, Olivia y Young, Kate (comps.), 1979, El mito del matriarcado. Antropología y feminismo, Barcelona, Anagrama.

Herrero, Miguel (1941), «Jauja», Revista de Indias, núm. 5 (1941), pp. 156-167.

Leonard, Irving A. (1954), Los libros del conquistador, México, FCE.

Libro de Alexandre, ed. de Francisco Marcos Marín, edición digital de la Biblioteca Virtual Miguel de Cervantes, Alicante, 2000, sobre la de Madrid, Alianza, 1987.

Luna, Lola G. (1982) «Androcentrismo e Historia de América. Las amazonas», Boletín Americanista de la Facultad de Geografía e Historia de la Universidad de Barcelona, vol. 24, núm. 32 (1982), pp. 305-312.

Mataix, Remedios (2009a), «Redescubriendo América: el modelo cronístico en la narrativa del Mundonovismo», en Guillermo Serés (coord.), Los limites del océano: estudios filológicos de Crónica y épica en el Nuevo Mundo, Barcelona, Universidad Autónoma de Barcelona, 2009, pp. 105-133.

- (2009b), «Las cinturas de América. Alegoresis, recurrencias y metamorfosis en la iconología americana», en José María Ferri Coll y José Carlos Rovira (eds.), Parnaso de dos mundos. De literatura española e hispanoamericana en el Siglo de Oro, Madrid, Iberoamericana-Vervuet, pp. 371425.

Martín Casares, Aurelia (2006), Antropología del género. Culturas, mitos y estereotipos sexuales, Madrid, Cátedra.

Mártir de Anglería, Pedro (1989), Décadas del Nuevo Mundo, Madrid, Polifemo.

Molina, Tirso de (2008), Amazonas en las Indias, ed. digital de la Biblioteca Virtual Miguel de Cervantes, 2008, sobre la de Miguel Zugasti, Trilogía de los Pizarros, vol. III, Kassel, Edition ReichenbergerFundación Obra Pía de los Pizarro, 1993.

Ortelius, Abraham (1570), Theatrum Orbis Terrarum, ed. facsímil digital de la Biblioteca Nacional de Chile (www.memoriachilena.cl).

Pané, Ramón (1974), Relación acerca de las antigüedades de los indios, ed. de José Juan Arrom, México, Siglo XXI editores, 1974.
Pastor, Beatriz (1983), Discurso narrativo de la conquista de América, La Habana, Casa de las Américas.

Pigafetta, Antonio (1941), Primer viaje en torno del Globo, trad. y ed. de Federico Ruiz Morcuende, Madrid, Espasa-Calpe.

Polo, Marco (1983), Viajes. Libro de las cosas maravillosas del Oriente, Madrid, Akal.

Pseudo Calístenes (1977), Vida y hazañas de Alejandro de Macedonia, Madrid, Gredos.

Raleigh, Walter (1986), El descubrimiento del grande, rico y bello imperio de Guayana, Caracas, Ediciones Juvenal Herrera.

Ripa, Cesare (2007), Iconología, ed. de Juan Barja, Yago Barja, Rosa María Mariño Sánchez y Fernando García Romero, Madrid, Akal.

Rodríguez de Montalvo, Garci (2003), Sergas de Esplandián, ed. de Carlos Sáinz de la Maza, Madrid, Castalia.

Said, Suzanne (1985), «Usages de femmes et sauvagerie dans l'ethnographie grecque d'Herodote à Diodore et Strabon", en A. M. Vérilhac (dir.), La femme dans le monde mediterranéen, I: Antiquité, Lyon, Maison de l'Orient.

Sales Dasí, Emilio (1998), "California, las amazonas y la tradición troyana», Revista de literatura medieval, X (1998), pp. 147167.

Schmidel, Ulrich (2001), Viaje al Río de la Plata, ed. digital de la Biblioteca Virtual Miguel de Cervantes, Alicante, 2001, sobre la de Buenos Aires, Cabaut y Cía., 1903.

Sobol, Donald J. (1973), The Amazons of Greek Mythology, New York, Bames.

Taufer, Alison (1991), «The Only Good Amazon is a Converted Amazon: The Woman Warrior and Christianity in the Amadis Cycle», en Jean R. Brink (ed.), Playing with Gender: A Renaissance Pursuit, Urbana, University of Illinois Press.

Thevet, André (1983), Les singularités de la France Antarctique, París, La Découverte/ Maspero.

Tobar Donoso, Julio (ed.), 2004, Historiadores y cronistas de las misiones, ed. digital de la Biblioteca Virtual Miguel de Cervantes, Alicante, 2004, sobre la de México, J. M. Cajica, 1960.

Tyrrel, William (1990), Las amazonas. Un estudio de los mitos atenienses, México, FCE, 1990.

Vega, Lope de (1916), Obras Completas I, Madrid, RAE, 1916.

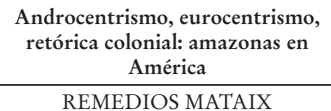

Androcentrismo, eurocentrismo, América

REMEDIOS MATAIX 
- (1980), El Nuevo Mundo descubierto por Cristóbal Colón, ed. de Jean Lemartinel y Charles Minguet, París, Lille.

Vespucci, Americo (1951), El Nuevo Mundo. Cartas relativas a sus viajes $y$ descubrimientos, ed. de Roberto Levillier, Buenos Aires, Nova.

Walcot, Peter (1984), «Greek Attitudes towards Women: The Mythological Evidence», Greece E Rome, núm. 31 (1984), pp. 35-46.

Weibaum, Batya (1999), Island of Women and Amazons. Representations and Realities, Austin, University of Texas Press.
Zugasti, Miguel (1998), «La alegoría de América en el teatro barroco español hasta Calderón de la Barca», en Mercedes Peña y Concepción Reverte (coords.), América y el teatro español del siglo de oro, Cádiz, Universidad de Cádiz.

- (2006), La alegoría de América en el barroco hispánico: del arte efímero al teatro, Valencia, Pre-textos.
Androcentrismo, eurocentrismo, retórica colonial: amazonas en América

REMEDIOS MATAIX 